\title{
The Chinese Trade Union Goes Abroad: Evidence from Cambodia
}

\section{Ivan Franceschini}

\section{(2) OpenEdition \\ 1 Journals}

\section{Electronic version}

URL: https://journals.openedition.org/chinaperspectives/11168

DOI: 10.4000/chinaperspectives. 11168

ISSN: 1996-4617

\section{Publisher}

Centre d'étude français sur la Chine contemporaine

\section{Printed version}

Date of publication: 1 December 2020

Number of pages: 29-37

ISSN: 2070-3449

\section{Electronic reference}

Ivan Franceschini, "The Chinese Trade Union Goes Abroad: Evidence from Cambodia", China Perspectives [Online], 2020/4 | 2020, Online since 01 December 2021, connection on 10 December 2021. URL: http://journals.openedition.org/chinaperspectives/11168; DOI: https://doi.org/10.4000/ chinaperspectives.11168 


\title{
The Chinese Trade Union Goes Abroad: Evidence from Cambodia
}

\author{
IVAN FRANCESCHINI
}

\begin{abstract}
In recent years, the All-China Federation of Trade Unions (ACFTU), the only trade union legally allowed in China, has become increasingly assertive on the international stage. Successive amendments to its constitution demand that the ACFTU not only assist the Chinese authorities in pushing forward the Belt and Road Initiative (BRI), but also reshape the current order of the international labour movement. Through the testimonies of local trade unionists, this paper examines how the ACFTU is attempting to achieve these goals in Cambodia, a country with large inflows of Chinese investment. The article will show that the Chinese trade union in Cambodia consistently engages with local Cambodian government-aligned actors that are usually neglected by the international labour movement, providing them with material assistance and opportunities to travel abroad. It argues that the impact of these activities should not be dismissed, as their alignment with the illiberal agenda of the Cambodian authorities and the priorities of employers has the potential to drastically change the landscape of trade unionism in Cambodia.
\end{abstract}

KEYWORDS: ACFTU, trade unions, China, Cambodia, Belt and Road Initiative.

In international affairs, Chinese trade unions uphold the policy of independence and autonomy, mutual respect, seeking common ground while acknowledging differences, reinforcing cooperation, and boosting friendship. On the basis of the principles of independence, equality, mutual respect, and mutual non-interference in internal affairs, they broadly establish and develop friendly relationships with union organisations at the international level and in every country, actively join in the establishment of the Belt and Road Initiative (BRI), advance the friendship between the working class in our country and the working classes in every country, and together with the unions and workers in the whole world strive for world peace, development, cooperation, worker rights, and social progress by playing a role in building up a community of shared destiny for mankind.

Statute of the All-China Federation of Trade Unions (ACFTU), as amended in $2018^{1}$

As a mass organisation of Leninist imprint and the sole trade union legally allowed in China, the ACFTU has been widely criticised for its perceived inability to represent the interests of its constituency. However, not much attention has been paid to the increasingly assertive international role that this organisation has begun to play in recent years. The Chinese union does not mince words when expressing its global ambitions. Already in 2013, an amendment to its constitution called for it to "promote the formation of a fair, rational, democratic, and harmonious new international order for the labour movement." ${ }^{\text {2 }}$ While this claim was dropped in 2018 in favour of the formulation reported above, "forming a new order for the international labour movement" (xingcheng guoji gongyun xin zhixu 形成國際工運新秩 序) remains one of the basic tasks for a "socialist trade union with Chinese characteristics" (jianchi Zhongguo tese shehuizhuyi gonghui 堅持中國特 色社會主義工會). ${ }^{3}$ In the context of the BRI, the ACFTU is also expected to play an active role through people-to-people diplomacy and cultural exchanges and by helping Chinese companies to build harmonious labour relations with foreign workers, thus contributing to their sustainable growth. ${ }^{4}$

But what kind of model is the ACFTU trying to promote? How do its activities actually impact the situation on the ground in other countries? Cambodia provides some preliminary answers to these questions. In November 2017, the Chinese and Cambodian authorities officially pledged to "increase human resources training in order to strengthen cooperation between unions and Chinese factory owners in the kingdom," and in order to achieve this goal, Cambodian unionists were invited to China to "learn about and improve the labour sector." ${ }^{15}$ On the occasion, Cambodian Labour Minister Ith Samheng warned Cambodian unionists to "work hard with the

1. “中國工會章程 (2018年10月26日中國工會第十七次全國代表大會通過)” (Zhongguo gonghui zhangcheng (2018 nian 10 yue 26 ri Zhongguo gonghui di shiqi ci quanguo daibiao dahui tongguo), Constitution of the Chinese trade union (as passed at the Seventeenth National Congress of Chinese Trade Unions on 26 October 2018)), ACFTU website, http://www.acftu.org/ template/10041/file.jsp?cid=1257\&aid=97208 (accessed on 23 April 2020)

2. “中國工會章程 中國工會第十六次全國代表大會部分修改 2013年10月22日通過)” (Zhongguo gonghui zhangcheng (Zhongguo gonghui di shiliu ci quanguo daibiao dahui bufen xiugai, 2013 nian 10 yue 22 ri tongguo), Constitution of the Chinese trade union (as partially amended at the Sixteenth National Congress of Chinese Trade Unions, approved on 22 October 2013)), ACFTU website, http://acftu.people.com.cn/n1/2017/0526/c412682-29302637.html (accessed on 23 April 2020).

3. “如何理解堅持中國特色社會主義工會發展道路?" (Ruhe lijie jianchi Zhongguo tese shehuizhuyi gonghui fazhan daolu?, How to understand the development path of a socialist trade union with Chinese characteristics), 工人日報 Workers' Daily, 11 December 2018, http://acttu. people.com.cn/n1/2018/1211/c67583-30457582.html (accessed on 23 April 2020).

4. ACFTU/OECD-TUAC Seminar, 27 May 2015, http://en.acftu.org/28612/201505/28/1505 28142253162.shtml (accessed on 23 April 2020); "中國工會積極參與'一帶一路'建設” (Zhongguo gonghui jiji canyu "yidai yilu" jianshe, Chinese trade union actively participates in the establishment of "BRI"), ACFTU website, 12 May 2017, http://www.acftu.org/template/10041/file. jsp?aid=94240 (accessed on 23 April 2020).

5. "China to boost training for unions," Khmer Times, 29 November 2017, https://www. khmertimeskh.com/92998 (accessed on 23 April 2020). 
Chinese," because "Cambodian unions will not be welcomed in Europe or the United States due to the current political situation in the country" - a retort to the international backlash against the latest authoritarian turn of Hun Sen's government. ${ }^{6}$ That very month, the ACFTU signed an undisclosed agreement with the Cambodian Civil Society Alliance Forum (CSAF), an umbrella organisation for local unions and NCOs established in 2016 by the Cambodian government with the goal of "[supporting] the development of the country through civil society in accordance with Cambodia's national development policy."

The cooperation between the two sides was officially launched on 23 April 2018, when the ACFTU invited a group of Cambodian trade unionists affiliated with CSAF for a weeklong visit to China that began with an event in Beijing framed as part of the Chinese union's "human exchange" (renwen jiaoliu 人文交流) activities related to BRI..$^{8}$ In the usual official jargon reserved for these occasions, the meeting was presented, among other things, as a means to "deepen the exchanges between workers in the two countries, as well as strengthen the understanding of the Cambodian unions and workers regarding the BRI and the [role of the] ACFTU in establishing harmonious labour relations, protecting the rights and interests of workers, carrying forward the spirit of model workers and craftmanship, etc." ${ }^{\prime \prime}$ All of this was supposed to be achieved "through lectures, informal discussions, study sessions on specific topics, visits to companies, and cultural tours."

The Cambodian experience is a perfect case for studying the ACFTU's international reach for at least two reasons. First, since the mid-1990s Cambodia has witnessed the growth of indigenous trade unions of considerable strength and diversity, including not only a broad cohort of government-aligned unions but also a lively independent labour movement. Such a diversified landscape makes it a perfect testing ground to assess how the ACFTU operates in a context of union pluralism. Second, in recent years China has poured a huge amount of investment into Cambodia. Between 2000 and 2017, Chinese investment accounted for $23 \%$ of all foreign investment in the country, which makes China the largest foreign investor by far. ${ }^{11}$ As a result of this large influx of investment, China has come to play a disproportionate role in Cambodian politics, including labour politics, a situation that amplifies any impact that the ACFTU's activities may eventually have (Lawreniuk 2019).

In examining the activities of the ACFTU in Cambodia and analysing the responses of local actors, this paper will contribute to the existing academic literature on the Chinese trade union, which largely neglects the international dimension of this organisation, with just a few exceptions (for instance, see Page 2017 and Quan 2018). The importance of this relatively unexplored topic is clear if we consider that the ACFTU is not only the largest trade union in the world, but also plays an increasingly important role within the International Labour Organisation (ILO) and in other international settings, as evidenced by the fact that in 2019 the Chinese union signed a South-South Cooperation Agreement with the ILO to assist trade union development in the Asia and the Pacific region. ${ }^{12}$

In addition to shedding light on the ACFTU's activities abroad, this paper will also enrich the debate regarding the social impact of Chinese outbound investment. In recent years, there has been much discussion about what Ching Kwan Lee has labelled the "spectre of global China," with Chinese capital "widely perceived as 'unnatural' in a neoliberal world order that otherwise naturalises the market and upholds the principle of free capital flow as sacrosanct" (Lee 2017: 1). While some authors have indeed highlighted severe labour rights violations committed by Chinese investors abroad (Halegua 2018), others have criticised the idea of the exceptionality of Chinese capital, highlighting instead how Chinese foreign investment shows a remarkable ability to adapt to local practices rather than changing them (Smith and Zheng 2016; Mueller 2018; Reisach 2018).

However, while these studies mostly focus on industrial relations and labour rights violations at the workplace level, it is important to point out that Chinese investment does not happen in a void. As Lee has observed, Chinese investors have to contend with local political economic and social pressures, in a process of constant contestation that, in some cases, ends up empowering local actors such as the state or civil society in the target countries (Lee 2017: 9). In light of these tensions, Ruben Gonzalez-Vicente has recently argued for the need to shift attention away from the moment of actual capitalist accumulation to the moment of "pre-distribution," which he defines as "the broader societal and institutional frameworks that accompany a type of investment in the first place and which exist in symbiotic relationships with specific forms of capital" (Gonzalez-Vicente 2020: 165).

Heeding this suggestion to look at the broader societal context that surrounds Chinese investment, I ask the two questions that are at the centre of this paper: How does the ACFTU engage with local trade unions in Cambodia? What are the potential implications of these engagements for the Cambodian labour movement and, consequentially, for investors from China and elsewhere? In particular, the article will show that in Cambodia the Chinese trade union consistently engages with local government-aligned actors that are usually shunned by the international labour movement, providing them with material assistance and opportunities to travel abroad. While the actual impact of these exchanges remains to be seen as this cooperation is only at the beginning, the article discusses the appeal of the Chinese trade union for this cohort of Cambodian unionists, as well as the way this attraction shapes their understanding of what a union is and how it should work. It also argues that these activities have the potential to change the landscape of trade unionism in Cambodia, as they align with the interests of both state authorities and employers and take place in the context of broader legal reforms and a crackdown on trade unions and civil society. In fact, both the government and the business community at large in Cambodia have a significant stake in seeing the Cambodian labour movement tamed through the reinforcement of friendly trade unions under a corporatist framework - the former to ensure the social and political stability essential to its survival, the latter to make sure that their operations are not disrupted by worker unrest.

The article is structured in four parts. The first section briefly outlines the structure of the ACFTU, as well as the constraints and limitations that it faces in its operations. The second focuses on the Cambodian trade unions,

6. Ibid.

7. See the organisation's official website at http://csaf.org.kh/en/about-csaf-2.

8. “開啓中國與柬埔寨職工人文交流的大門: 中柬職工交流營在京開營” (Kaiqi Zhongguo yu Jianpuzhai zhigong renwen jiaoliu de damen: Zhongjian zhigong jiaoliuying zai Jing kaiying, Opening the door for human exchanges between Chinese and Cambodian workers and employees: The Sino-Cambodian Worker and Employee Camp starts in Beijing), I 人日報 Workers' Daily, 24 April 2018, http://www.acftu.org/template/10041/file. jsp? cid=1079\&aid=96070 (accessed on 23 April 2020).

9. Ibid.

10. Ibid.

11. Mark Grimsditch, "The Cambodia Conundrum: The Belt and Road, Private Capital and China's 'Non-interference' Policy," Panda Paw Dragon Claw, 25 June 2019, https://pandapawdragonclaw. blog/2019/06/25/the-cambodia-conundrum-the-belt-and-road-private-capital-and-chinas-noninterference-policy (accessed on 23 April 2020).

12. "ILO and All-China Federation of Trade Unions Join Forces to Implement Decent Work in Asia Pacific," International Labour Organization website, 15 June 2019, https://www.lo.org/actrav/ media-center/pr/WCMS_710621/lang--en/index.htm (accessed on 21 July 2020). 
describing the historical process that led to the emergence of a highly diverse labour movement in the country and the challenges this movement faces today. The third delves into the cooperation between the ACFTU and Cambodian unions through the voices of Cambodian trade unionists who have travelled to China on the invitation of their Chinese counterparts or who have participated in other activities organised by the ACFTU. Finally, the conclusion discusses the implications of my findings in the context of China's global push.

The paper is based on 31 semi-structured interviews with Cambodian union leaders, staff at labour NGOs, and government officials conducted between 2018 and 2019. Through snowball sampling, I interviewed 22 officials in government-aligned trade unions and associations that have exchanges with China (in three cases, more than once); four leaders of independent trade unions; two officials at the CSAF; and two labour NGO staff members. While snowball sampling is often problematic in that it tends to skew the sample towards people with similar backgrounds and attitudes, in this specific case it was a suitable method to reach out to a relatively tightly-knit group of Cambodian unionists who shared the experience of travelling to China. These interviews also built on information collected during dozens of interviews with Cambodian trade unionist, labour activists, labour lawyers, and government officials that I have carried out over the past five years. Unfortunately, every effort I made to contact the ACFTU in Beijing to interview Chinese union officials involved in the exchanges with Cambodia was fruitless.

\section{The Chinese trade union}

First established in Guangzhou in 1925, in the midst of the turmoil of the Republican era, to this day the ACFTU remains a classic example of a Leninist trade union, structured according to the principle of "democratic centralism" and functioning as a "transmission belt" between the Party-state and the workers (Harper 1969). Given its huge membership - around 300 million members according to the latest counts - and its important role in boosting the legitimacy of the Chinese Communist Party, the Chinese union is unlikely to undergo any substantial change anytime soon. Indeed, at the Sixteenth National Congress of the ACFTU, held in October 2013, Prime Minister Li Keqiang expressed the hope that "trade unions at all levels continue to develop their role of bridge and link (qiaoliang he niudai 橋梁和紐帶) between the Party and government and the masses of the workers and employees, rallying these broad masses to the cause of the modernisation of the country."13 Such expectations of the Chinese leadership were confirmed almost verbatim at the Seventeenth Congress that took place five years later. $^{14}$

Some scholars have emphasised how the ACFTU plays an important role in drafting new rules and regulations related to workers, thanks to its embeddedness in the Party-state (Unger and Chan 1995; Gallagher and Dong 2011). Others have highlighted how it is not possible to treat the ACFTU as a monolithic entity, as the organisation is very diverse from both a geographical and hierarchical point of view (Liu 2010). However, most of the literature focuses on the limitations and inefficiency of this organisation. To cite just a few critical views, a 2007 article by Bill Taylor and Li Qi argues that, by a number of criteria, the ACFTU cannot even be considered a trade union: its constitutional mandate of protecting the interests of the workers as union members conflicts with its duty to ensure the rights of the working class (and therefore the nation) as a whole; it lacks internal democracy; and it enjoys an unhealthy legal monopoly over worker representation by virtue of its ties to the Party-state. Similarly, Feng Chen (2009) shows that while union bureaucracies can play an active role in labour legislation and labour disputes, at the grassroots level the subordination of workplace unions to management leaves them with no power whatsoever. Adopting a broader perspective, Patricia Chen and Mary Gallagher (2018: 1032) further highlight how the state's appropriated representation of labour through the ACFTU acts as a key "political fix" in preventing the emergence of a labour movement in China.

In recent years, attempted reforms within the ACFTU have made headlines on several occasions, but in every instance, excitement was soon followed by disappointment. For instance, back in 2006, the ACFTU successfully unionised Walmart stores in China (Blecher 2008). Since the Walmart unions were established through an underground organising drive by local union cadres, Chinese and international media hailed this as a turning point for the Chinese union, boosting the image of the ACFTU worldwide. Unfortunately, later studies showed that these new unions very quickly fell into the usual path of unresponsiveness and lack of transparency and democracy (Chan 2011). A few years later, in May 2010, workers at a Honda transmission auto-spare parts factory in Nanhai successfully mobilised, achieving a pay rise of $33 \%$ and a promise to hold genuine elections for the union branch committee (Chan and Hui 2012). Although hailed as a watershed for the Chinese labour movement, expectations regarding union elections were promptly disappointed in the following year, when seats on the newlyelected union committee were swept up mostly by management staff (Lau 2012). Overall, while over the past two decades the ACFTU has made experiments in democratic elections at the grassroots level a cornerstone of its propaganda, such elections remain at most indirect and quasi-democratic, and rarely succeed in building accountable workplace union branches (Chan 2015; Hui and Chan 2015: 621).

The limitations of the ACFTU emerge clearly also from its experience with collective bargaining. In the Chinese context, the confrontational nature of "collective bargaining" (jiti tanpan 集體談判) - which implies a conflict of interests between employers and employees - was watered down to a process of simple "collective negotiation" (jiti xieshang 集體協商) based on the assumption of a substantial unity of interests between company and workers and on a formalistic approach in which collective contracts generally did not include any provisions beyond the legal minimum (Brown 2006). This has not prevented Chinese unions from experimenting with different practices at the local or industrial level as part of top-down ACFTU reform (Friedman 2014; Wen and Lin 2015), and occasionally local branches of the Chinese union have been able to develop relatively efficient practices of collective bargaining (Pringle and Meng 2018; Froissart, Liu, and Meng 2019). However, that these experiments remain highly localised is highlighted by the fact that in recent years it took labour NCOs to enable the emergence in China of authentic "worker-led collective bargaining" in which workers are able to put forward demand that go beyond the legal minimum (Froissart

13. “李克强: 讓改革發展成果惠及全體人民” (Li Keqiang: rang gaige fazhan chengguo huiji quanti renmin, Li Kegiang: Let the achievements of the reforms extend to all people), 新華 Xinhua, 21 October 2013, http://news.xinhuanet.com/politics/2013-10/21/c_117809444.htm (accessed on 23 April 2020); “習近平與中華全國總工會新一届領導班子集體談話” (Xi Jinping yu Zhonghua quanguo zonggonghui xin yi jie lingdao banzi jiti tanhua, Xi jinping holds a collective discussion with the new leadership of the ACFTU), 新華 Xinhua, 23 October 2013, http://www. gov.cn/ldhd/2013-10/23/content_2513659.htm (accessed on 23 April 2020).

14. “李克强在中國工會十七大做經濟形勢報告" (Li Keqiang zai Zhongguo gonghui di shiqi da zuo jingji xingshi baogao, Li Keqiang delivers the report on the economic trends at the Seventeenth Congress of the ACFTU), Central government website, 24 October 2018, http:// www.gov.cn/xinwen/2018-10/24/content_5334173.htm (accessed on 23 April 2020). 
2018). All of this has made the ACFTU largely irrelevant in the eyes of the Chinese workers - an irrelevance that, in turn, makes one wonder what kind of lessons this organisation might want to impart to its foreign partners.

\section{Trade unions in Cambodia}

Cambodian trade unions share the same Leninist roots as the ACFTU. After the end of the Khmer Rouge regime in 1979, for a decade Cambodia was run by a government backed by the Vietnamese, which attempted to reorganise the country's economy in a centralised fashion. To facilitate central control and planning, the Cambodian authorities proceeded to establish a network of state-sponsored associations that included "syndicates" in government ministries or agencies in provinces and districts (Nuon and Serrano 2010: 20). Following the classic Leninist approach, the government considered these syndicates "not only as core groups for conveying messages from the members to the state and vice versa, but also as mass organisations representing the voice of the people" (ibid.). Like the Chinese trade union today, the Cambodian syndicates of the 1980s were also involved in the provision of social services, the organisation of recreational activities for their membership, and the education of the poor and illiterate.

With the retreat of the Vietnamese in 1989 and the subsequent end of the international embargo, the Cambodian government shifted to a development strategy based on widespread privatisation and foreign investment (Slocomb 2010). In this new context, the older syndicates lost purpose and were largely absorbed into the government bureaucracy. The Paris Peace Agreements of 1991 paved the way for the United Nations to take over the government of Cambodia through the United Nations Transitional Authority in Cambodia (UNTAC), pending the organisation of democratic elections in 1993. In those early years of peace, foreign donors came to hold disproportionate power over Cambodian politics, largely determining its course. Eager to gain international recognition, the Cambodian authorities incorporated into their legislative activity key concepts such as civil society, good governance, decentralisation, gender equality, and human rights (Slocomb 2006: 391). This discourse was enshrined in the Cambodian Constitution of 1993, which included commitment to the rule of law and to human rights, including specific protection of labour rights such as the right of citizens to choose their employment, equal pay for equal work, guaranteed employment for women during pregnancy, the right to maternity leave, freedom of association, and freedom to strike (Adler and Woolcock 2009: 170).

Such a discourse not only fostered a vibrant civil society in Cambodia, but also led to a surge of activism by workers within Phnom Penh's newlyestablished garment industry in the mid-1990s. Those early mobilisations were prompted not so much by issues of pay, but of treatment by nonKhmer speaking foreign managers, especially Chinese, including violence or threats of violence against individuals, forced overtime, or racist slurs (Hughes 2007: 842). The year 1996 saw the establishment of the Free Trade Union of Workers of the Kingdom of Cambodia (FTUWK), which immediately sought to establish ties with the international trade union movement and civil society (Arnold and Shih 2010: 406). Unlike China, where the Party-state dominates the political landscape and there is no room for any organised opposition, the existence of an authentic political opposition to Hun Sen's Cambodian People's Party (CPP) played a fundamental role in fostering independent unionism and in framing workers' grievances not so much in nationalistic discourse as in terms of "rights" (Hughes 2007; Norén-Nilsson 2016: 141, 185)

Other forces that played a role in nurturing an indigenous trade union movement include international NGOs, unions, and consumer groups, as well as the International Labour Organisation (ILO). Pressure from the ILO and US trade unions seeking to embed freedom of association and collective bargaining in the regulatory framework, both of which had been absent from labour legislation passed in 1992, resulted in legal provisions in the Cambodian Labour Law of 1997 that did not stipulate minimum membership to establish a trade union, or limit the number of unions that can represent workers in a single enterprise (Ward and Moyly 2016: 262). Still, since the simple passing of the law was not enough to improve labour conditions, in 1999 pressure from the international labour movement led to the stipulation of a Bilateral Textile Agreement between the US and Cambodia and the subsequent establishment of the ILO Better Factories Cambodia (BFC) programme - a monitoring system for the implementation of labour standards at the factory level as a condition of quota increases (Kolben 2004; Polaski 2006). Although after the end of the trade agreement with the United States in 2004 and the lifting of safeguard quotas imposed by the US government against China in 2008 the Cambodian authorities stopped their attempt to reposition the country as an "ethical" producer, all these developments nevertheless laid the groundwork for extraordinary growth in the number of trade unions in Cambodia.

While international NGOs and the ILO played a somewhat moderating role, seeking to de-link union issues from party politics and attempting to replace public worker public collective action with regimented forms of participation by selected representatives behind closed doors (Hughes 2007; Ward and Mouyly 2016; Arnold 2017), the ties that bound the earliest trade unions to the political opposition made the Cambodian government wary from the outset. On the one hand, to counter the rising influence of trade unions aligned with the opposition, the government and individual employers began to establish their own unions. These organisations pushed the view that unions could assist workers in achieving their rights without resorting to strikes, but by using negotiation and patronage instead. On the other hand, the authorities did not hesitate to resort to violence. The fact that international civil society was following closely what was going on in Cambodia did not prevent the 2004 killing, in broad daylight and in the centre of Phnom Penh, of Chea Vichea, the popular leader of the FTUWK, a murder that is widely believed to have been politically motivated and whose perpetrators were never apprehended. More unionists from the same organisation were to be murdered in the following years.

While shocking, these events did not stop the growth of a trade union movement in Cambodia. Indeed, according to official data of the Cambodian Ministry of Labour and Vocational Training, in 2019 the country had as many as 28 union confederations, 180 federations, and 4,351 grassroots unions. ${ }^{15}$ Beside the opposition-aligned and government-aligned unions, in the late 1990s a third kind of organisation emerged: so-called "independent unions" that emphasised their political neutrality and nurtured strong ties to international civil society. Still, in terms of density, trade union membership remains quite low, with estimates that put the unionisation rate of the entire Cambodian workforce around $1 \%$, with the significant exception of the garment industry, where more than $60 \%$ of workers are unionised (Nuon and Serrano 2010: 1).

The existing literature highlights a series of challenges and structural limitations that Cambodian trade unions have to face. First, on a day-today basis, Cambodian unionists have to confront threats and intimidation

15. E-mail communication with the Phnom Penh office of the American Centre for International Labor Solidarity, 7 November 2019. 
by employers, as well as attempts to buy them off. Many of them are simply laid off, and find it almost impossible to seek new employment (HRW 2015 : 76-81). Second, employers exploit the political divisions among unions to undermine the solidarity among workers and their ability to mobilise (Oka 2015: 665). Third, employers in the garment sector have increasingly moved toward the use of informal and flexible short-term and daily labour to curtail union membership and force workers to agree to otherwise unacceptable conditions (Yale Law School 2011). Finally, there is clearly a gap in internal union democracy, which causes gender bias and a certain disconnect between union leaders and their constituency, a situation particularly evident in the garment sector, where an almost entirely female workforce is represented mostly by male unionists (Arnold 2017: 28).

The year 2014 marked a watershed moment for the Cambodian labour movement. From 24 December 2013 to early January 2014, tens of thousands of garment workers went on strike, demanding that the government double the minimum wage (AMRC 2014). For almost two weeks, the mobilisation paralysed the entire Cambodian industrial system until the morning of 3 January 2014, when military police opened fire on the striking workers in an industrial area on the outskirts of Phnom Penh, killing four and injuring around 40 (AMRC 2014: 21). In the wake of these events, the Cambodian authorities acted quickly to reinforce their grip on the unions among a more general crackdown on the political opposition and on independent media. First, six prominent leaders of independent unions who were involved in the strikes were brought to court on spurious charges of instigating intentional acts of violence, intentionally causing damage, threats to destroy followed by an order, and blocking public traffic. ${ }^{16}$ In December 2018, they were all found guilty, but a few months later the charges were dropped in appeal, after Prime Minister Hun Sen himself, in a curious act of political theatrics, intervened on behalf of the accused. ${ }^{17}$ Second, in April 2016, the Cambodian authorities passed a controversial Trade Union Law that established a series of strict requirements for the process of union registration, imposed burdensome reporting obligations, and further limited the unions' ability to organise strikes. ${ }^{18}$ Although the law was amended in 2019, the concerns of independent unions have scarcely been addressed. ${ }^{19}$ It is in such a tense context that the ACFTU began ramping up its activities in Cambodia.

\section{The ACFTU in Cambodia}

In Cambodia, the ACFTU mostly engages with three local actors. The main partner is the National Union Alliance Chamber of Cambodia (NACC), a trade union confederation established in 2007 after a split with the Cambodian Confederation of Trade Unions (CCTU), the main union confederation linked to the ruling party. At the time of my fieldwork, the NACC was led by Som Oun, a unionist who previously represented the employees of a small real estate company owned by an early unionist who had established a union federation close to the Prime Minister (Nuon and Serrano 2010: 77). According to my interviewees, in 2019 NACC claimed to have around 400,000 members in industries as diverse as rubber, garments and footwear, transportation, beer, and the informal sector. That Som Oun's political influence in Cambodia was on the rise was made abundantly clear in August 2019, when the National Council for Minimum Wage - an official body under the Ministry of Labour and Vocational Training - selected him as one of two vice presidents representing workers and employers to begin discussions on the minimum wage for garment and footwear factory workers in $20200^{20}$
NACC, in turn, is not only a member of CSAF, but also plays a leading role within the organisation, with Som Oun also being one of its deputy presidents. As mentioned above, CSAF was established in 2016 by the Cambodian government for the purposes of serving as an umbrella organisation to facilitate the interactions of local NGOs and community organisations with relevant government departments and to link them to potential international donors. According to my interviews with CSAF officials, by July 2019 the Forum had enlisted 180 Cambodian NGOs and community organisations, putting them in touch with donors from China to carry out projects in four fields: education, access to clean water, healthcare, and solar energy. ${ }^{21}$ At that time, China was the only country that had shown interest in cooperating with CSAF, as Western donors had been completely uninterested in the initiative, but my interviewees still held out some hope for Russia. ${ }^{22}$

The third Cambodian organisation the ACFTU engages with is the CCTU, the government-aligned union confederation from which the NACC separated in 2007 - a split that apparently was motivated more by personal clashes among the leadership than political reasons (Nuon and Serrano 2010: 75). At the time of my fieldwork, this organisations was led by an early unionist named Chuon Momthol, who has cooperated with the ACFTU since the late 1990s through his various organisations - first the Cambodian Union Federation (CUF) and then, since 2004, the CCTU - after establishing a personal connection with them at the margins of ILO meetings in Geneva. ${ }^{23}$ According to interviews with the CCTU leadership, in January 2019 the organisation claimed to have over 300,000 members in various industries, including garment and footwear, construction, fishing, kilns, and casinos. ${ }^{24}$

While Chuon Momthol's organisations have cooperated with the ACFTU for two decades, with their leadership making regular trips to China and receiving some material aid, the focus of the ACFTU in Cambodia today is the NACC. Exchanges between the ACFTU and NACC within the framework of the BRI started around 2014, but then took off at the end of 2016, after the establishment of the CSAF. So far, the cooperation has involved frequent paid study trips to China for Cambodian union officials - as many as 30 people at a time - and occasional visits by delegations from national and provincial branches of the ACFTU. In 2018, the ACFTU also presented the NACC with two brand-new buses sent directly from China - two very fancy vehicles that "look like a plane" and which, according to one of my interviewees, were used by the union leadership to organise visits to some tourist sites. ${ }^{25}$ In addition, at the time of my fieldwork, the NACC and the ACFTU were in the process of negotiating an Memorandum of Understanding that included

16. Niem Chheng, "Union Leader Six Found Guilty over Violent Protests in 2018," The Phnom Penh Post, 12 December 2018, https://www.phnompenhpost.com/national/union-leader-six-foundguilty-over-violent-protests-2013 (accessed on 23 April 2020).

17. Mom Kunthear, "Appeal Court Overturns Convictions of Six Unionists," Khmer Times, 30 May 2019, https:/www.khmertimeskh.com/609128/appeal-court-overturns-convictions-of-sixunionists (accessed on 23 April 2020).

18. Mong Palatino, "The Trouble with Cambodia's New Law on Trade Unions," The Diplomat, April 2016, http://thediplomat.com/2016/04/the-trouble-with-cambodias-new-law-on-trade-unions (accessed on 23 April 2020)

19. Long Kimmarita, "Trade Union Bill Changes Passed," The Phnom Penh Post, 13 October 2019, https://www.phnompenhpost.com/national/trade-union-bill-changes-passed (accessed on 23 April 2020).

20. Mom Kunthear, "Minimum Wage Council Selects Vice Presidents," Khmer Times, 30 August 2019, https://www.khmertimeskh.com/50638520/minimum-wage-council-selects-vice-presidents (accessed on 15 September 2020).

21. Interviews in Phnom Penh, 26 July 2019.

22. Ibid.

23. Interview in Phnom Penh, 10 January 2019.

24. Ibid.

25. Interview in Phnom Penh, 2 November 2018. 
provisions for the Chinese union to provide trainings, additional vehicles to be used to transport workers from their lodgings to the factories (for a fee), and an entire building to accommodate the NACC bureaucracy. Yet, in August 2019, discussions about the MoU were still ongoing, with some of my interviewees explaining this delay with the need to figure out the practicalities of the cooperation, as several local branches of the ACFTU and layers of the NACC were involved. ${ }^{26}$

More than the material side of the cooperation, my research aimed at understanding how Cambodian unionists receive the ACFTU's message. In my interviews, I asked my interlocutors to elaborate on the traits of the ACFTU that they found most appealing. The responses invariably focused on two issues: financial stability and efficiency. In their meetings with Cambodian unionists, ACFTU officials consistently emphasised the financial strength and sustainability of their organisation. According to Article 42 of the Chinese Trade Union Law, trade unions in China can count on five sources of funding: a) membership fees paid by the members; $b$ ) monthly allocations of $2 \%$ of the total wages of all of its employees paid to a trade union by the enterprise, public institution, or government organ that established the trade union; c) income turned in by the enterprise or public institutions to which the trade union is subordinate; d) people's government subsidies; and e) other income. In Cambodia, on the contrary, although unions receive varying degrees of support from international donors, government agencies, or even employers depending on their alignment, membership fees are the most important source of income for these organisations. In the eyes of most of my interviewees, this was a significant challenge and a constant source of disgruntlement, as they found themselves dedicating much of their time chasing new members or preventing existing member from dropping off or joining competing unions just to ensure the financial survival of their organisations.

ACFTU officials were adept at capitalising on this dissatisfaction, fostering the myth of the Chinese trade union as a highly efficient organisation. The message is that allowing only one union per workplace frees unionists from financial concerns and from the need to compete with each other, allowing them to really focus on their activities for the benefit of the workers. Most of my interviewees in government-aligned unions indeed fell for this narrative and looked up to the Chinese union as a model that - although difficult to implement in the Cambodian context due to political divergences in the labour movement - would be highly desirable. In the words of one of them:

I think what Cambodian unions should learn from the ACFTU is how to deal with their finances. I mean, employers and workers should both pay some. Also, our unions should merge into one, so wherever we are, they know what we have been up to: one direction, one goal, and one benefit. $^{27}$

This was accompanied by considerable self-deprecation, with my interviewees constantly playing down the achievements of the labour movement in Cambodia. Asked whether they thought that China had anything to learn from the experience of the Cambodian trade unions, few had anything positive to say. This response from another pro-government unionist is emblematic: "I can say that we don't have much for them to learn from us, since our development is lagging far behind compared to them. We have so many more problems than China. Especially, they don't have as many strikes and protests as we have."${ }^{128}$ When challenged about the limitations of the ACFTU, only a few of my interviewees in pro-government unions reluctantly acknowledged the downside of a single-union system. For instance, one of them stated: "China should have two or three unions, so if there is anything wrong the other unions can complain. ${ }^{\prime 29}$ Yet, a few minutes after he had left the meeting place, he called back to correct this answer: the right response was that China was doing totally fine with a single union.

Another aspect of the ACFTU that often caught the attention of the Cambodian trade unionists was its perceived opulence. In her study of the international diplomacy of the Chinese trade union, Page (2017: 110) quotes an official in a Taiwanese union who participated in an event organised by the ACFTU in 2009. According to this person, the meeting "took place at the historic Diaoyutai State Guesthouse in Beijing, involved a highlevel prestigious reception and the organisers continuing to give gifts to the participants, which were said to have included goose down jackets, lightweight suitcases, traditional Chinese writing instruments and wine amongst other gifts." My Cambodian interviewees were equally dazzled by the hospitality they received from their Chinese hosts. As one official from a government-aligned union recounted,

I feel very honoured and grateful. If I didn't join the trade union, I would never have had an opportunity to go to China in my whole life. It was very impressive for me to see the landscape, the culture, and a lot of things that can be a good example for us... One more important thing, we were treated as an official delegation from our country. They paid for us to stay in expensive hotels that cost no less than 100 USD per night, and everyone got his own room in a five-star hotel..$^{30}$

This was in striking contrast with the experience that my interviewees in the pro-government camp had with Western trade unions and labour NGOs. Their only interactions at the international level were with trade unions in the neighbouring Laos and Vietnam - cash-strapped organisations structured on Leninist lines just like the ACFTU - and they resented being excluded from most events organised by Western organisations. As one of them explicitly stated: "The Americans or the Europeans never invite us to join their activities because we work with the government, but we need to be trained too, just like other unions. ${ }^{131}$ They were also particularly aggrieved because the European Union chose to funnel most funding through NCOs - a grudge that some independent unionists also shared - and unfavourably compared the EU's procedures regarding transparency and reporting to China's laissez faire attitude:

China's work focuses on the government, while the EU focuses on NCOs. So for China, they process the funding through CSAF, which is a government department. China doesn't have to worry about corruption in the usage of funding - it is not their problem, because, as we all know, before we get any funding the money must goes through the Ministry of Economy and Finance, so we cannot do anything the way we want. The EU instead trusts the people they fund upon presentation of reports [laughing], but they are very detailed about funding, they have a proper system for this. We can't cheat them even one cent. ${ }^{32}$

\footnotetext{
26. Interview in Phnom Penh, 9 August 2019

27. Interview in Phnom Penh, 31 July 2019.

28. Interview in Phnom Penh, 1 November 2018

29. Interview in Phnom Penh, 31 July 2019.

30. Interview in Phnom Penh, 6 November 2018.

31. Interview in Phnom Penh, 2 November 2018

32. Interview in Phnom Penh, 2 November 2018
} 
While Western donors were perceived as excessively strict regarding procedure, it was widely believed that in working with them, and especially with the EU, it did not really matter what happened to the money: the only skill that mattered was to be able to write nice-sounding reports coached in technical language. Since mastering such a skill is far from easy, engaging with China felt much more convenient. As this latter unionist remarked regarding the massive influx of aid and investment from China: "I can say that having all of this in Cambodia is not ideal, but better than nothing. Without them, it would be hard for us."133

\section{Discussion}

In sum, in Cambodia the ACFTU only interacts with government-aligned actors that are usually neglected by the international labour movement, providing them with material assistance and opportunities for international exchanges and training. In so doing, it capitalises on their disgruntlement about the status quo, particularly the lack of resources and stability. Those Cambodian unionists who return from China come back with a very positive impression of their Chinese host, dazzled by the perceived opulence, efficiency, and financial stability. If their understanding of the workings of the ACFTU remains very superficial, their impression of the Chinese union mostly reflects the limitations of their own organisations, i.e., the lack of financial resources, continuous in-fighting, and difficulties in growing and maintaining a membership. What makes the kind of trade unionism promoted by the ACFTU so appealing to government-aligned unions in Cambodia is the economic sustainability and the stability of an organisational model based on the existence of a single organisation in the workplace, accompanied by legal provisions for a stable stream of income from company payrolls. Sacrificed on the altar of this fascination is the acknowledgment of the importance of union pluralism in order to ensure workplace democracy.

The evidence I have presented can be interpreted in two ways. On the one hand, the activities of the ACFTU could be dismissed as simple public diplomacy not too different from that in which trade unions in the West engage. After all, the ACFTU is establishing relationships with governmentaligned organisations that, while numerically strong, have a dubious hold on their constituency, are largely unaccountable to their members, and lack any standing at the international level. There is no doubt that providing them with a few dozen vehicles, possibly a building, and a few paid trips to China is not going to change that. On the other hand, while it is highly doubtful that the ACFTU alone would be able to effect any significant change on the Cambodian labour movement, the risk becomes all too real if we consider how its activities align with the illiberal agenda of the Cambodian authorities, who in recent years have already cracked down hard on independent unions, and the priorities of foreign investors, who would like to see the local labour movement tamed. With the Cambodian government using outright repression and legal means to make it increasingly difficult for independent unions to register, the game is rigged, and any assistance to governmentaligned unions has the potential of having a disproportionate impact.

An emboldened cohort of government-aligned unions in Cambodia might vastly facilitate the activities of investors, whether from China or elsewhere. For instance, during a research trip to Sihanoukville in August 2019, I discovered that the NACC was one of only a handful trade unions - none of them independent ${ }^{34}$ - allowed to carry out activities targeting workers inside the Chinese-run Sihanoukville Special Economic Zone (SSEZ). Founded in 2008 by the Chinese company Jiangsu Taihu Cambodian International Economic Cooperation Investment Co. Ltd. in collaboration with a local partner, the SSEZ has since come to be considered a BRI signature project in Cambodia. In March 2020, the industrial park hosted more than 170 firms and employed 30,000 workers, with further expansion plans calling for 300 companies and 100,000 employees (Loughlin and Grimsditch 2020). Unsurprisingly, according to an internal report by ACILS, SSEZ factory owners have "a coordinated strategy of labour disempowerment and exploitation," regularly blacklisting unruly workers who attempt to organise unions or express discontent, and circulating their photos and details to other managers (Blau, undated). That the NACC has been able to carry out activities to such a context shows how a certain style of trade unionism can also be alluring to employers. It is this appeal to employers - Chinese or not - and to authoritarian governments eager to tame their workers that alerts us to how the ACFTU, backed by the power of the Chinese state and capital, might eventually be able to actually achieve its ambitious goal of "forming a new order for the international labour movement."

This also has broader implications for our understanding of the dynamics of Chinese foreign investment. While it is true that, as Ching Kwan Lee (2017) has argued, a healthy local civil society can act as a powerful constraint for Chinese investment, and eventual abuses by Chinese investors can even contribute to reinforcing local actors, we cannot overlook the fact that the Chinese Party-state is also attempting to exert an influence on those very actors that should act as a counterbalance through its own agencies and allies, including the ACFTU. Although this is not surprising if we consider that Western unions and NGOs have always attempted to reshape local civil society in their image - the history of the Cambodian labour movement outlined above presents a particularly clear instance of this kind of influence - what is problematic in the Chinese case are the illiberal values behind such activities. Although the ACFTU "model" might actually benefit some trade unions in Cambodia, it will be Cambodian workers who eventually will end up paying the price.

\section{Acknowledgements}

I I wish to thank my assistants Ratana Heng and Soun Sophea for their help in arranging the interviews on which this study is based, as well as all the Cambodian trade unionists who agreed to meet me to discuss their experience in China. Nicholas Loubere, Christian Sorace, and Anita Chan all provided important feedback on earlier drafts of this article, as did Hong Zhang and Mark Grimsditch. Finally, I am grateful to the two anonymous reviewers for their comments on successive versions of the paper.

I Ivan Franceschini is a Postdoctoral Fellow at the Australian Centre on China in the World, The Australian National University, and Co-editor-inChief of the open access quarterly Made in China Journal. China in the World Building \#188, Fellows Lane, The Australian National University Canberra ACT 2601, Australia (ivan.franceschini@anu.edu.au).

\section{Manuscript received on 28 April 2020. Accepted on 9 September 2020.}

33. Ibid.

34. "Independent Union Does Not Exist to Protect Rights and Working Conditions of Workers in Sihanoukville Special Economic Zones," Cambodian Center for Independent Media, 19 November 2018, https://ccimcambodia.org/?p=1289 (accessed on 13 September 2020). 


\section{References}

ADLER, Daniel, and Michael WOOLCOCK. 2009. "Justice without the Rule of Law? The Challenge of Rights-based Industrial Relations in Contemporary Cambodia." World Bank Justice and Development Working Paper Series 2(2): 163-86.

AMRC. 2014. A Week that Shook Cambodia: The Hope, Anger, and Despair of Cambodian Workers after the General Strike and Violent Crackdown. Hong Kong: Asia Monitor Resource Centre.

ARNOLD, Dennis. 2017. "Civil Society, Political Society and Politics of Disorder in Cambodia." Political Geography 60: 23-33.

ARNOLD, Dennis, and Toh Han SHIH. 2010. "A Fair Model of Globalization? Labour and Global Production in Cambodia." Journal of Contemporary Asia 40(3): 401-24.

BLAU, Gavan. Undated. Cambodian SEZ Index. Unpublished report produced by the Phnom Penh Office of the American Centre for International Labor Solidarity.

BLECHER, Marc. 2008. "When Wal-Mart Wimped Out: Globalization and Unionization in China." Critical Asian Studies 40(2): 263-76.

BROWN, Ronald C. 2006. "China's Collective Contracts Provisions: Can Collective Negotiations Embody Collective Bargaining?" Duke Journal of Comparative \& International Law 16(1): 35-78.

CHAN, Anita. 2011. "Unionizing Chinese Walmart Stores." In Anita Chan (ed.), Walmart in China. Ithaca, NY: Cornell University Press. 199216.

CHAN, Anita. 2015. "Trade Union Elections at Foreign-owned Chinese Factories." China: An International Journal 13(3): 94-113.

CHAN, Chris King-chi, and Elaine Sio-leng HUI. 2012. "The Dynamics and Dilemma of Workplace Trade Union Reform in China: The Case of the Honda Workers' Strike." Journal of Industrial Relations 54(5): 653-68.

CHEN, Feng. 2009. "Union Power in China: Source, Operation, and Constraints." Modern China 35(6): 662-89.

CHEN, Patricia, and Mary GALLAGHER. 2018. "Mobilization without Movement: How the Chinese State 'Fixed' Labor Insurgency." ILR Review 71(5): 1029-52.

FRIEDMAN, Eli. 2014. Insurgency Trap: Labor Politics in Postsocialist China. Ithaca, NY: Cornell University Press.

FROISSART, Chloé. 2018. "Negotiating Authoritarianism and Its Limits: Worker-led Collective Bargaining in Guangdong Province." China Information 32(1): 23-45.

FROISSART, Chloé, Yan LIU, and Quan MENG. 2019. "Trade-offs between State Organisations and Workers' Organisations." China Perspectives 2(117): 29-38.

GALLAGHER, Mary, and Baohua DONG. 2011. "Legislating Harmony: Labor Law Reform in Contemporary China." In Sarosh Kuruvilla, Ching Kwan Lee, and Mary Gallagher (eds.), From Iron Rice Bowl to Informalization: Markets, Workers, and the State in a Changing China. Ithaca, NY: Cornell University Press and ILR Press. 36-60.
GONZALEZ-VICENTE, Ruben. 2020. "Varieties of Capital and Predistribution: The Foundations of Chinese Infrastructural Investment in the Caribbeans." Made in China Journal 5(1): 164-68.

HALEGUA, Aaron. 2020. "Where is China's Belt and Road Leading International Labour Rights? An examination of worker abuse by Chinese construction firms in Saipan." In Maria Adele Carrai and Jan Wouters (eds.), The Belt and Road Initiative and Global Governance. Cheltenham: Edward Elgar Publisher.

HARPER, Paul. 1969. "The Party and the Unions in Communist China." The China Quarterly 37: 84-119.

HUMAN RIGHTS WATCH. 2015. "'Work Faster or Get Out': Labor Rights Abuses in Cambodia's Garment Industry." https://www.hrw.org/ sites/default/files/reports/cambodia0315_ForUpload.pdf (accessed on 23 April 2020).

HUI, Elaine Sio-ieng, and Chris King-chi CHAN. 2015. "Beyond the Union-centred Approach: A Critical Evaluation of Recent Trade Union Elections in China." British Journal of Industrial Relations 53(3): 60127.

HUGHES, Caroline. 2007. "Transnational Networks, International Organizations and Political Participation in Cambodia: Human Rights, Labour Rights and Common Rights." Democratization 14(5): 834-52.

KOLBEN, Kevin. 2004. "Trade, Monitoring, and the ILO: Working to Improve Conditions in Cambodia's Garment Factories." Yale Human Rights \& Development Law Journal 7: 79-120.

LAU, Rena. 2012. "Restructuring the Honda Auto Parts Union in Guangdong, China: A 2-year Assessment of the 2010 Strike." Working USA: The Journal of Labor and Society 15(4): 497-515.

LAWRENIUK, Sabina. 2019. "'Hun Sen Won't Die, Workers Will Die:' The Geopolitics of Labour in the Cambodian Crackdown." Made in China Journal 3(3): 82-5.

LEE, Ching Kwan. 2017. The Specter of Global China: Politics, Labor, and Foreign Investment in Africa. Chicago, IL:The University of Chicago Press.

LIU, Mingwei. 2010. "Union Organizing in China: Still a Monolithic Labor Movement?" ILR Review 64(1): 30-52.

LOUGHLIN, Neil, and Mark GRIMSDITCH. 2020. "'Not China's Solo, but a Symphony Performed by All Relevant Countries': How Political Economy Dynamics in Recipient States Are Shaping the Belt and Road Initiative." Unpublished working paper.

MUELLER, Wolfgang. 2018. "Chinese Investors in Europe: A Threat to Jobs and Labour Standards?" Made in China Journal 3(4):34-9.

NORÈN-NILSSON, Astrid. 2016. Cambodia's Second Kingdom: Nation, Imagination, and Democracy. Ithaca, NY: Cornell Southeast Asia Program Publication.

NUON, Veasna, and Melisa SERRANO. 2010. Building Unions in Cambodia: History, Challenges, Strategies. Singapore: FES Office for Regional Cooperation in Asia. 
OKA, Chikako. 2016. "Improving Working Conditions in Garment Supply Chains: The Role of Unions in Cambodia." British Journal of Industrial Relations 54(3): 647-72.

PAGE, Rachel C. 2017. "China's International Labour Relations: The Evolution and Politics of China's Interactions with the International Labour Movement and Overseas Labour Organisations." PhD Dissertation, Department of Public Policy, City University of Hong Kong.

POLASKI, Sandra. 2006. "Combining Global and Local Forces: The Case of Labour Rights in Cambodia." World Development 34(5): 919-32.

PRINGLE, Tim, and Quan MENG. 2018. "Taming Labor: Workers' Struggles, Workplace Unionism, and Collective Bargaining on a Chinese Waterfront." ILR Review 71(5): 1053-77.

QUAN, Katie. 2018. "Prospects for US-China Union Relations in the Era of Xi and Trump." Made in China Journal 2(3): 48-53.

REISACH, Ulrike. 2018. "Strategic Considerations of Chinese Investors in Europe." Made in China Journal 3(4): 28-33.

SLOCOMB, Margaret. 2006. "The Nature and Role of Ideology in the Modern Cambodian State." Journal of Southeast Asian Studies 37(3): 375-95.

SLOCOMB, Margaret. 2010. An Economic History of Cambodia in the Twentieth Century. Singapore: NUS Press.
SMITH, Chris, and Yu ZHENG. 2016. "The Management of Labour in Chinese MNCs Operating Outside of China: A Critical Review." In Mingwei Liu and Chris Smith (eds.), China at Work: A Labour Process Perspective on the Transformation of Work and Employment in China. London: Palgrave Macmillan. 366-81.

TAYLOR, Bill, and Qi LI. 2007. "Is the ACFTU a Union and Does It Matter?" Journal of Industrial Relations 49(5): 701-15.

UNGER, Jonathan, and Anita CHAN. 1995. "China, Corporatism, and the East Asian Model." The Australian Journal of Chinese Affairs 33: 2953.

WARD, Kristy, and Vichhra MOUYLY. 2016. "Employment Relations and Political Transition in Cambodia." Journal of Industrial Relations 58(2): 258-72.

WEN, Xiaoyi, and Kevin LIN. 2015. "Restructuring China's State Corporatist Industrial Relations System: The Wenling Experience." Journal of Contemporary China 24(94): 665-83.

YALE LAW SCHOOL. 2011. "Tearing Apart at the Seams: How Widespread Use of Fixed Duration Contracts Threatens Cambodian Workers and the Cambodian Garment Industry." https://www.law.yale. edu/system/files/documents/pdf/Intellectual_Life (accessed on 23 April 2020). 